\title{
PHYSIOLOGICAL CHARACTERISTICS RELATED TO CARBON SEQUESTRATION OF TREE SPECIES IN HIGHLAND FOREST ECOSYSTEM OF MOUNT HALIMUN-SALAK NATIONAL PARK
}

\author{
Nuril Hidayati ${ }^{1,2}$, M. Mansur and Titi Juhaeti \\ Received : 8 March 2010, Accepted : 15 February 2012
}

\begin{abstract}
Biological diversity can have significant contribution to reduce the build-up of greenhouse gases in the atmosphere. The trees in a forest stand form an essential part in the functioning of the terrestrial biosphere, especially in the carbon cycle. Yet tree photosynthesis is far less studied than crop photosynthesis for several reasons: the large number of species; difficulty in measuring photosynthesis of entire trees or of forest stands. This research aims to assess the contribution of biological diversity in carbon sequestration by analyzing the physiological characteristics (photosynthesis, transpiration, stomatal conductance, leaf chlorophyll content) of species native to tropical highland forest ecosystem of Mount Halimun-Salak National Park. The results showed that there was a wide range of variation of $\mathrm{CO}_{2}$ assimilation rate between tree species. The overall $\mathrm{CO}_{2}$ absorption rate ranged $1.1913-31.3875$ $\mu \mathrm{molm} \mathrm{s}^{-1}$, the highest rate was reached by Lithocarpus sp. (pasang parengpeng) $\left(31.3875 \mu \mathrm{molm}^{-2} \mathrm{~s}^{-1}\right)$, followed by Litsea noronbae (huru lumlum) (21.5750 $\left.\mu \mathrm{molm}^{-2} \mathrm{~s}^{-1}\right)$, Saurania nudiflora (kilebo) (11.8175 $\mu$ molm $\left.{ }^{-2} \mathrm{~s}^{-1}\right)$, Vernonia arborea (hamirung) $\left(6.7125 \mu \mathrm{molm}^{-2} \mathrm{~s}^{-1}\right)$ and Litsea sp. (huru bodas) $(6.2725 \mu \mathrm{molm}$ $\left.{ }^{2} \mathrm{~s}^{-1}\right)$. The rate of $\mathrm{CO}_{2}$ assimilation was affected by incident radiation and thus the photon flux (Q leaf). Correlation between $\mathrm{CO}_{2}$ assimilation and $\mathrm{Q}$ leaf under certain environmental condition was considerably high. Incident radiation and Q leaf also affected stomatal conductance and thus rate of transpiration.
\end{abstract}

Keywords: Biological diversity, photosynthesis, carbon sequestration, greenhouse gases

\section{INTRODUCTION}

Forests represent $21 \%$ of the continental area which are $76 \%$ of terrestrial biomass and $37 \%$ of its bioproductivity (Ceulmans and Sauger, 1991). A biologically diverse tropical forest holds 50 times more carbon per unit of area than a monoculture plantation. Thus, the trees in a forest stand form an essential part in the functioning of the terrestrial biosphere, especially in the carbon cycle. Yet tree photosynthesis is far less studied than crop photosynthesis for several reasons: the large number of species; difficulty in measuring photosynthesis of entire trees or of forest stands.

Biological diversity can make a significant contribution to reducing the build-up of

${ }^{1}$ Biology Research Center - Indonesia Institute of Science

²Corresponding author:criantcht@yahoo.co.id greenhouse gases in the atmosphere. Each year about 60 gigatonnes (GT) of carbon (C) are taken up and released by land-based ecosystems and about $90 \mathrm{GT}$ are taken up and released by ocean systems. These natural fluxes are large compared to the approximately 6.3 GT being emitted from fossil fuels and industrial processes, and about 1.6 GT per year from deforestation (CBD, 2008).

A reliable method for restoration of forest and reforestation is using native tree species. The trees which are suitable for CDM (Clean Development Mechanism) purpose should have the three following characteristics; (1) seedling that can adapt easily to open sites, after transplanting from shade (nurseries) to the sunlit conditions; (2) fast-growing species that is able to compete with weeds and fern (Ashton, 1998); (3) tree species that have high $\mathrm{CO}_{2}$ assimilation 
capacity and long live. However, these physiological characteristics differ widely among tree species. In order to attain successful reforestation, it is necessary to carefully select appropriate trees for transplanting based on these characteristics. For evaluation of the appropriate trees, ecological (dominance, biomass, carbon content) and physiological (photosynthesis, transpiration) characteristics are suitable indicators (Takahashi et al., 2005, 2006; Ashton, 1998).

Variance in $\mathrm{CO}_{2}$ assimilation rate is large among trees grown under sunlit conditions not only across the continental transect as well as across tropical climate regions (Matsumoto et al., 2003). Fast-growing trees often have relatively higher $\mathrm{CO}_{2}$ assimilation rate in tropical climate zone suggesting that $\mathrm{CO}_{2}$ assimilation rate can be an indicator for evaluating fast-growing characteristics (Press et al., 1996, Matsumoto et al., 2003).

In this study ecological and physiological characteristics of tree species native to humid highland forest ecosystem examined. This research aimed to provide informations on tree characteristics related to high carbon sequestration by analyzing their physiological characteristics $\left(\mathrm{CO}_{2}\right.$ absorption, $\mathrm{CO}_{2}$ assimilation, stomatal conductance, chlofophyll content), and ecological characteristics (dominance, biomass production and carbon sequestration).

\section{MATERIAL AND METHODS}

\section{A. Study Site}

This study was conducted in two locations representing humid highland forest in Mount Halimun-Salak National Park : 1) Cikaniki and 2) Citalahab. Two plots were established in two different sites. The first plot of $100 \mathrm{~m} \times 100 \mathrm{~m}$ was located in Cikaniki station of $06^{\circ} 44^{\prime} 57^{\prime \prime} \mathrm{S}$ and $106^{\circ} 32^{\prime} 08^{\prime \prime} \mathrm{E}, 1,100 \mathrm{~m}$ above sea level and the second one of $50 \mathrm{~m} \times 50 \mathrm{~m}$ was located in Citalahab of $06^{\circ} 44^{\prime} 32.2^{\prime \prime} \mathrm{S}$ and $116^{\circ} 31^{\prime} 44.0^{\prime \prime} \mathrm{E}$, 1,076 $\mathrm{m}$ above sea level (Figure 1).

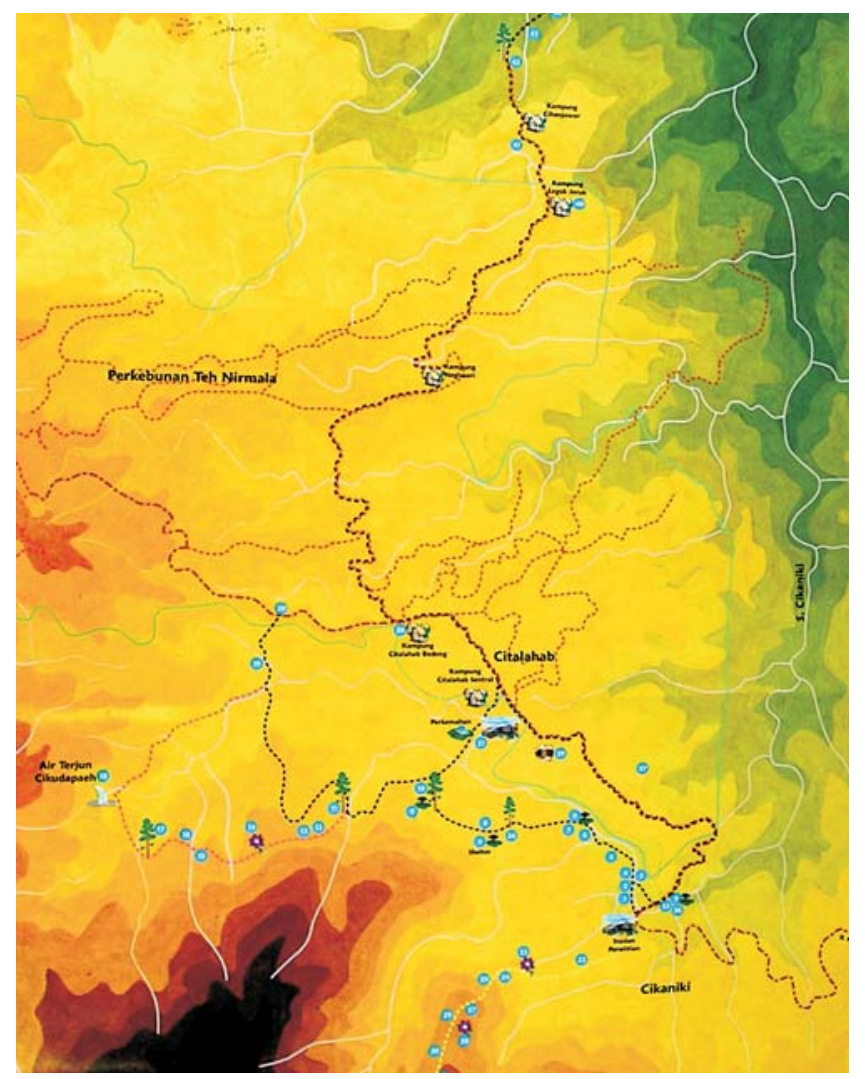

Figure 1. Cikaniki and Citalahab study sites in Mount Halimun-Salak National Park 


\section{B. Ecological Analysis}

Analysis of vegetation was conducted by making plots of representative sizes. Each plot was divided into smaller plots $10 \mathrm{~m} \times 10 \mathrm{~m}$. From these smaller plots assessment and identification were made for name of the tree species, number of species, stem diameter $(>10 \mathrm{~cm})$, height, coordinate of the trees $(\mathrm{x}, \mathrm{y})$. For the unknown species, samples were collected for identification.

The collected data was analyzed using Cox (1967) and Greigh-Smith (1964) method for obtaining the values of basal area, relative frequency, relative density, relative dominance and value of importance by the following calculation:

$$
\mathrm{BA}=(0.5 \times \mathrm{DD}) 2 \times 3.14
$$

Where BA $\left(\mathrm{m}^{-2} \mathrm{~h}^{-1}\right)$ is basal area; $\mathrm{D}$ is diameter and value of 3.14 is a constant.

Plant biomass and carbon content were estimated by using the following calculation:

$$
\mathrm{W}=\mathrm{a} \mathrm{D}^{\mathrm{b}}
$$

$\mathrm{W}=$ biomass; $\mathrm{a}$ and $\mathrm{b}=\mathrm{W}=$ biomass; $\mathrm{a}$ and $\mathrm{b}=$ constant for estimating biomass of tree community $(\mathrm{a}=0.19$ and $\mathrm{b}=2.37) ; \mathrm{D}=$ stem diameter (Brown, 1997).

$$
\begin{gathered}
\mathrm{C}=0.5 \mathrm{~W} \\
\mathrm{C}=\text { carbon content; } \mathrm{W}=\text { biomass. }
\end{gathered}
$$

\section{Physiological Analysis}

The measurement of physiological and photosynthetic characteristics were carried out in April and June 2010. The height of tree sampled was $50 \mathrm{~cm}-150 \mathrm{~cm}$. Simultaneous measurements of $\mathrm{CO}_{2}$ assimilation, stomatal conductance and transpiration were conducted by using portable LCi ADC Bioscientific Ltd. Photosynthesis System. The measurement of carbon dioxide $\left(\mathrm{CO}_{2}\right)$ uptake is a direct method of measuring carbon exchange, with important advantages: it is instantaneous and non destructive and it allows measurement of the total carbon gain by a plant separation of photosynthetic gain from respiratory loss. This measurement of $\mathrm{CO}_{2}$ exchange involved enclosure methods which is enclosure of a leaf in a transparent chamber.

The rate of $\mathrm{CO}_{2}$ assimilation by the leaf enclosed is determined by measuring the change in the $\mathrm{CO}_{2}$ concentration of the air flowing across the chamber. In this close system air is pumped from the chamber enclosing a leaf into an IRGA (Infra Red Gas Analyzer) which continuously records the $\mathrm{CO}_{2}$ concentration of the system. The air is then recycled back to the chamber. No air leaves or enters the system. If the leaf enclosed in the chamber as photo-synthesizing, the $\mathrm{CO}_{2}$ concentration in the system will decline, and continue to decline until the $\mathrm{CO}_{2}$ compensation point of photosynthesis is reached. The rate of $\mathrm{CO}_{2}$ assimilation is equal to the change in the amount of $\mathrm{CO}_{2}$ in the system per unit time.

Rate of $\mathrm{CO}_{2}$-assimilation was measured under certain range of $\mathrm{CO}_{2}$ concentrations, photon flux, and leaf temperature (Table 1). For measurement of physiological characteristic, a fully expanded (young) and older leaves were chosen per sampling. Three different plants individuals of each species were measured. Simultaneous measurements of microclimate, photosynthesis, chlorophyll content and transpiration rate were conducted. The measuring time for each species was between $09.00-12.00 \mathrm{am}$ under completely clear sky.

The measurement of microclimate was conducted for each plant species. Air temperature

Table 1. Range of $\mathrm{CO}_{2}$ concentration in stomata, $\mathrm{CO}_{2}$ reference, foton flux, vapour pressure and temperature (leaf and chamber) during the measurement.

\begin{tabular}{lcc}
\hline \multirow{2}{*}{ Parameters } & \multicolumn{2}{c}{ Halimun National Park } \\
\cline { 2 - 3 } & Cikaniki & Citalahab \\
\hline $\mathrm{CO}_{2}$ reference (cref: vpm) & $370-750$ & $371-433$ \\
$\mathrm{Analytical}_{\mathrm{CO}}(\mathrm{can}: \mathrm{vpm})$ & $360-703$ & $365-438$ \\
$\mathrm{CO}_{2}$ in stomata $(\mathrm{ci}: \mathrm{vpm})$ & $260-500$ & $345-412$ \\
Foton flux $\left(\mathrm{Qleaf:} \mu \mathrm{molm}{ }^{-2} \mathrm{~s}^{-}\right)$ & $8-250$ & $10.25-957$ \\
Chamber temperature $\left(\mathrm{Tch}^{\circ}{ }^{\circ} \mathrm{C}\right)$ & $24-29.5$ & $21.6-30.8$ \\
Leaf temperature(Tie: $\left.{ }^{\circ} \mathrm{C}\right)$ & $29-30$ & $20-29$ \\
Vapour pressure (P: mbar) & 900 & 900 \\
\hline
\end{tabular}


and relative humidity were measured using Digital Thermohygrometer AS ONE TH-321, soil $\mathrm{pH}$ and moisture content were measured using Soil Tester, and light intensity was measured by using Lux meter Luxor. Leaf chlorophyll content was measured using spectrophotometer and chlorophyll meter SPAD-502; Minolta Co.Ltd., Osaka, Japan.

\section{RESULTS AND DISCUSSION}

\section{A. Results}

1. Cikaniki Site

Tree distribution in the higher site was dominated by Altingia excelsa (rasamala) which contributed to $32 \%$ of the total basal area (BA), followed by Schima wallichii (puspa) (10\%) and Quersus lineata (6\%).

Microclimate and soil conditions during the measurements were presented in Appendix Table 1. Soil $\mathrm{pH}$ ranged from $5.58-6.60$, soil moisture ranged from $55.5-90.3 \%$, relative humidity was $62.5-29.4 \%$, air temperature ranged from 23.5 $29.4^{\circ} \mathrm{C}$ and light intensity was 597.5 - 22893.5 lux.

Under such microclimate and soil conditions the overall $\mathrm{CO}_{2}$ assimilation range from 1.1913 $31.3875 \mu$ molm $^{-2} \mathrm{~s}^{-1}$. The highest rate was reached by Lithocarpus sp.1 (pasang parengpeng) which was $31.3875 \mu \mathrm{molm}^{-2} \mathrm{~s}^{-1}$, followed by Litsea noronhae (huru lumlum) $21.5750 \mu^{2} \mathrm{molm}^{-2} \mathrm{~s}^{-1}$, Saurania nudiflora (kilebo) $11.8175 \mu_{\mathrm{molm}}^{-2} \mathrm{~s}^{-1}$, Vernonia arborea (hamirung) $6.7125 \mu_{\text {molm }}^{-2} \mathrm{~s}^{-1}$ and Litsea sp.1(huru bodas) which was $6.2725 \mu$ molm $^{-2} \mathrm{~s}^{-1}$ (Table 2).
The rate of transpiration ranged between $0.4175-1.8975 \mathrm{molm}^{-2} \mathrm{~s}^{-1}$. The highest was reached by Eugenia sp.1 (kibeusi) which was 1.8975, followed by Castanopsis acuminatissima (kianak) $1.8950 \mathrm{molm}^{-2} \mathrm{~s}^{-1}$, Quercus lineata (pasang batarua) $1.7875 \mathrm{molm}^{-2} \mathrm{~s}^{-1}$, Schima wallichii (puspa) $1.6225 \mathrm{molm}^{-2} \mathrm{~s}^{-1}$ and Litsea noronbae (huru lumlum) which was 1.5300 molm $^{-2} \mathrm{~s}^{-1}$ (Table 2).

Chlorophyll content of the leaf varied between $0.6015-3.8370 \mathrm{mg}$ chlorophyll. The highest leaf chlorophyll content was on Symplocos fasciculata (jirak) which was 3.8370, followed by Litsea sp.2 (huru hejo) 3.2862, Litsea bracbystachia (huru hiris) 3.1232, Litsea sp.3 (huru buah) 2.7065 and Litsea sp.1(huru bodas) 2.6268 (Table 2).

Variation in microclimate conditions during the measurements resulted in variation of the measurements. The rate of $\mathrm{CO}_{2}$ assimilation was affected by incident radiation intensity and thus the quantum leaf ( $Q$ leaf) (Figure 2). Incident radiation and $\mathrm{Q}$ leaf also affected stomatal conductance and thus rate of transpiration. Correlation between stomatal conductance and transpiration rate was $\mathrm{R}=0.5741$ (Figure 3).

$\mathrm{CO}_{2}$ assimilation of young leaves was not significantly different with that of older leaves, although stomatal resistance of young leaves was commonly higher than that of old leaves (Appendix 2). Under such environmental conditions $\mathrm{CO}_{2}$ assimilation was affected more by external factors (i.e. solar radiation) than by the leaf stomatal character although some theory stated that stomatal conductance correlates with photosynthetic capacity (Wong et al., 1979). Under certain range of $\mathrm{Q}$ leaf, there was a linear

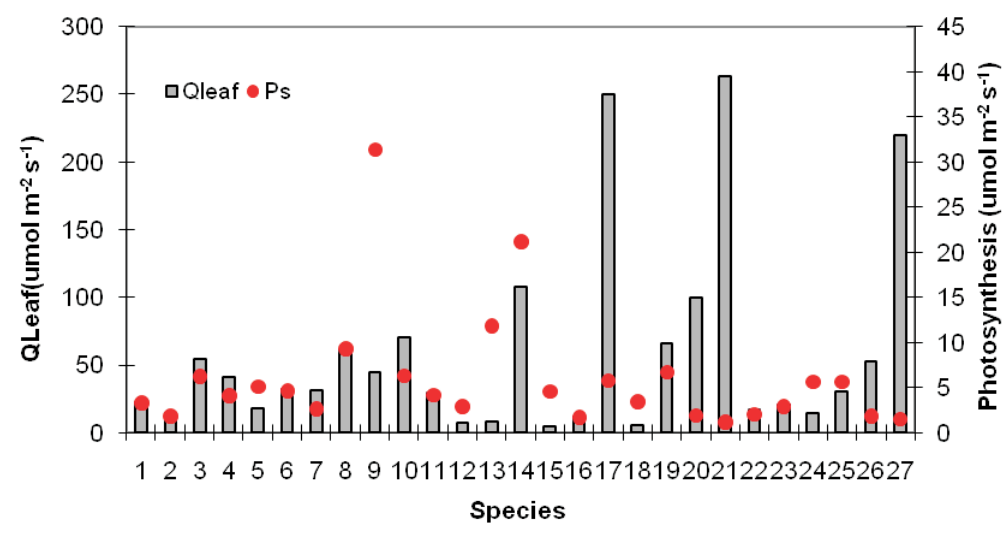

Figure 2. Correlation between photon flux (QLeaf) and photosynthesis (Ps) In Cikaniki plot (names of species are presented in Table 2) 
Physiological Characteristics Related to Carbon Sequestration of Tree Species tn Highland Forest Ecosystem ..... (Nuril Hidayati)

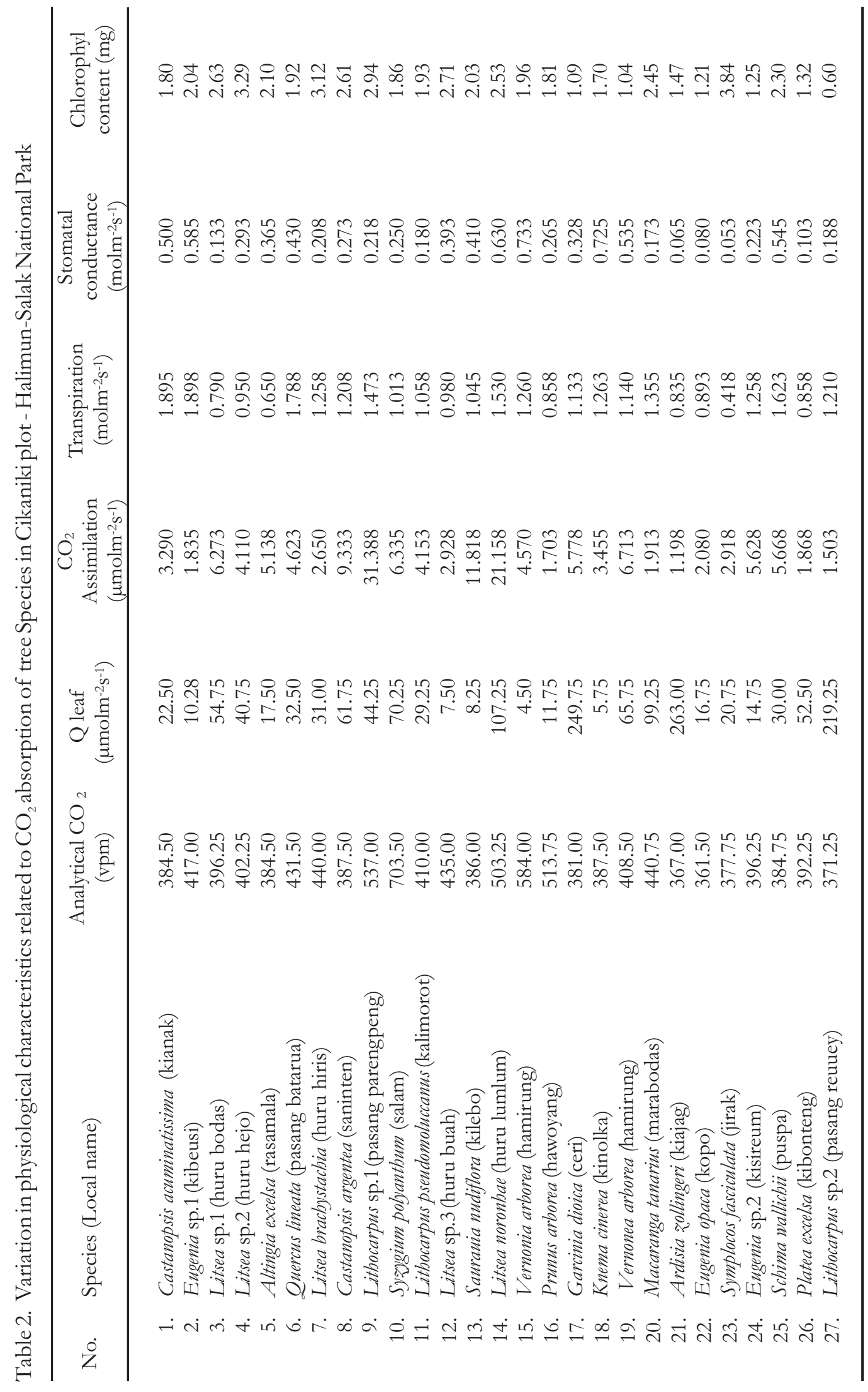




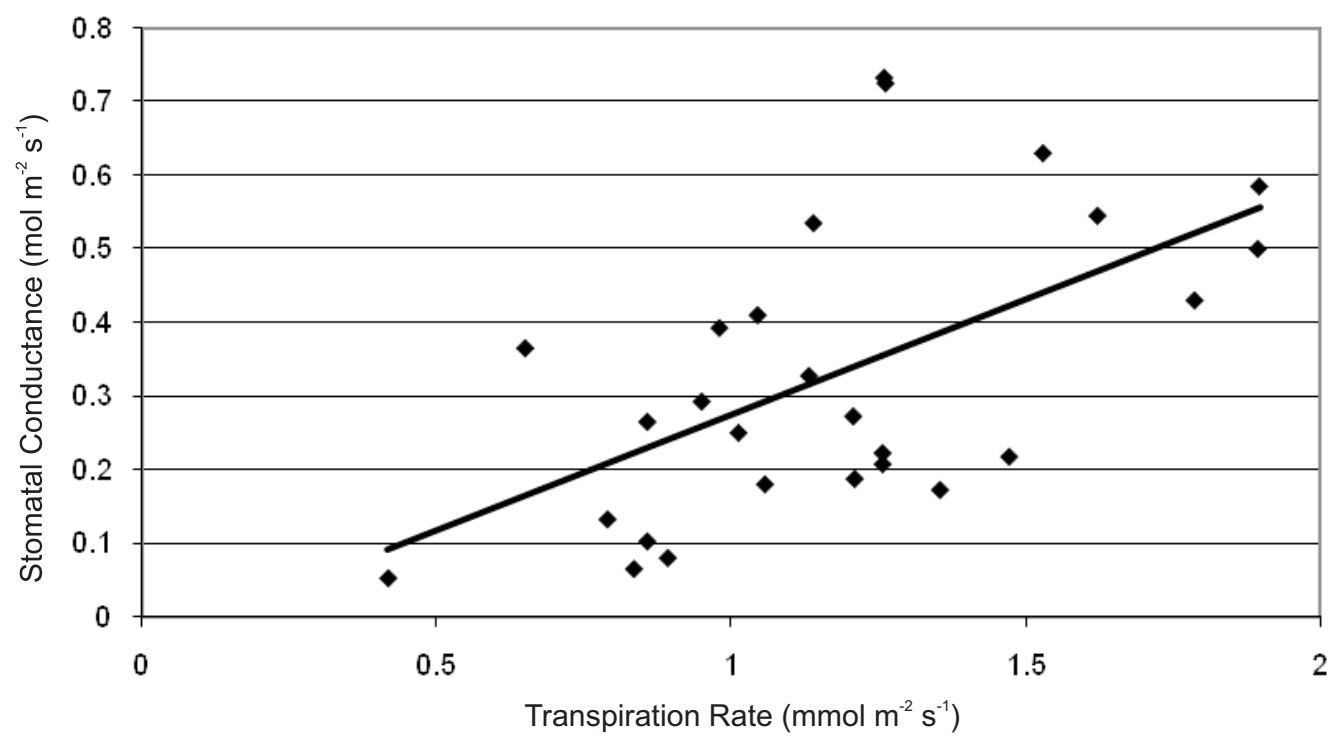

Figure 3. Correlation between stomatal conductance and transpiration in Cikaniki Plot $(R=0.5741)$

relationship between $\mathrm{CO}_{2}$ assimilation $\mathrm{Q}$ leaf. This findings agree with the report by Long and hallgren (1993). There was positive correlation between $\mathrm{CO}_{2}$ assimilation and leaf chlorophyll content although the value was not significant. However this relationship need to be studied more thoroughly under controlled environment.

\section{Citalahab Site}

In Citalahab plot, there were 337 individual trees (diameter $>10 \mathrm{~cm}$ ) which consists of 71 species from 32 genus and 50 families. The most commonly family found were Lauraceae, Fagaceae, Myrtaceae, Rubiaceae, Meliaceae and Euphorbiaceae.

There were 20 trees species that have the highest "value of importance" including Altingia excelsa, Blumeodendron elateriospermum, Ardisia zollingeri, Gordonia excelsa, Tricalysia singularis, Castanopsis acuminatissima, Knema cinerea, Laportea stimulans, Vernonia arborea and Dysoxylum excelsum.

Distribution of diameter classification was dominated by class $10-20 \mathrm{~cm}$, that reached $51.63 \%$ of the total individu. The most common tree species within this class include Ardisia zollingeri, Laportea stimulans, Gordonia excelsa and Urophyllum glabrum.
Microclimate conditions during the measurement were relatively low temperature and low light intensity (Appendix 3). This microclimate conditions resulted in low photon flux (Q leaf) and relatively low in $\mathrm{CO}_{2}$ assimilation rate. The highest $\mathrm{CO}_{2}$ assimilation rate in this area was $8.77 \mu \mathrm{molm}^{-2} \mathrm{~s}^{-1}$ (Altingia excelsa), followed by Tricalysia singularis which was $7.10 \mu \mathrm{molm}^{-2} \mathrm{~s}^{-1}$ and Litsea resinosa which was $6.22 \mu_{\mathrm{molm}} \mathrm{s}^{-1}$ (Table 3 and Figure 4). Variation in transpiration rate and stomatal conductance were relatively small under this environmental conditions. Under certain conditions, there was positive correlation between $\mathrm{Q}$ leaf and $\mathrm{CO}_{2}$ assimilation and between stomatal conductance and transpiration rate although the values were relatively low due to the uncontrolled environmental factors.

Dry matter and carbon content reached 152,247.91 (152.3 ton ha ${ }^{-1}$ ) obtained from basal area of $28.89 \mathrm{~m}^{-2} \mathrm{ha}^{-1}$ and the number of individu 337 trees ha ${ }^{-1}$. Five tree species with the highest biomass were recorded i.e.: Altingia excelsa (938.25 ton $\mathrm{ha}^{-1}$ ), Blumeodendron elateriospermum (2882.31 ton $\mathrm{ha}^{-1}$ ), Castanopsis acuminatissima (1930.21 ton $\left.\mathrm{ha}^{-1}\right)$, Engelhardtia serrata (1608.47 ton $\mathrm{ha}^{-1}$ ) and Vernonia arborea (1372.75 ton ha $\left.{ }^{-1}\right)$. The ecological findings are discussed in different paper. 
Physiological Characteristics Related to Carbon Sequestration of Tree Species tn Highland Forest Ecosystem ..... (Nuril Hidayati)

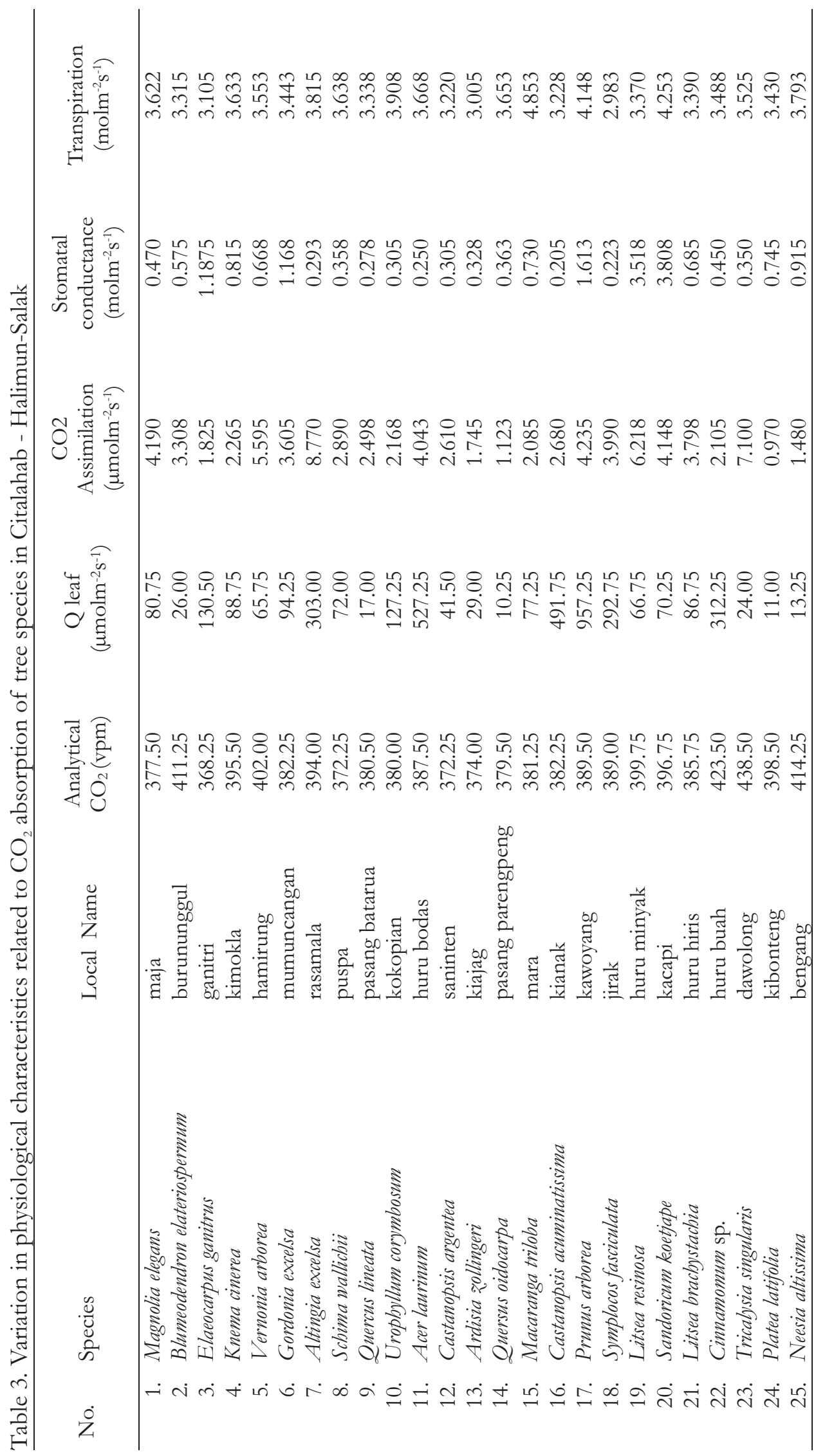




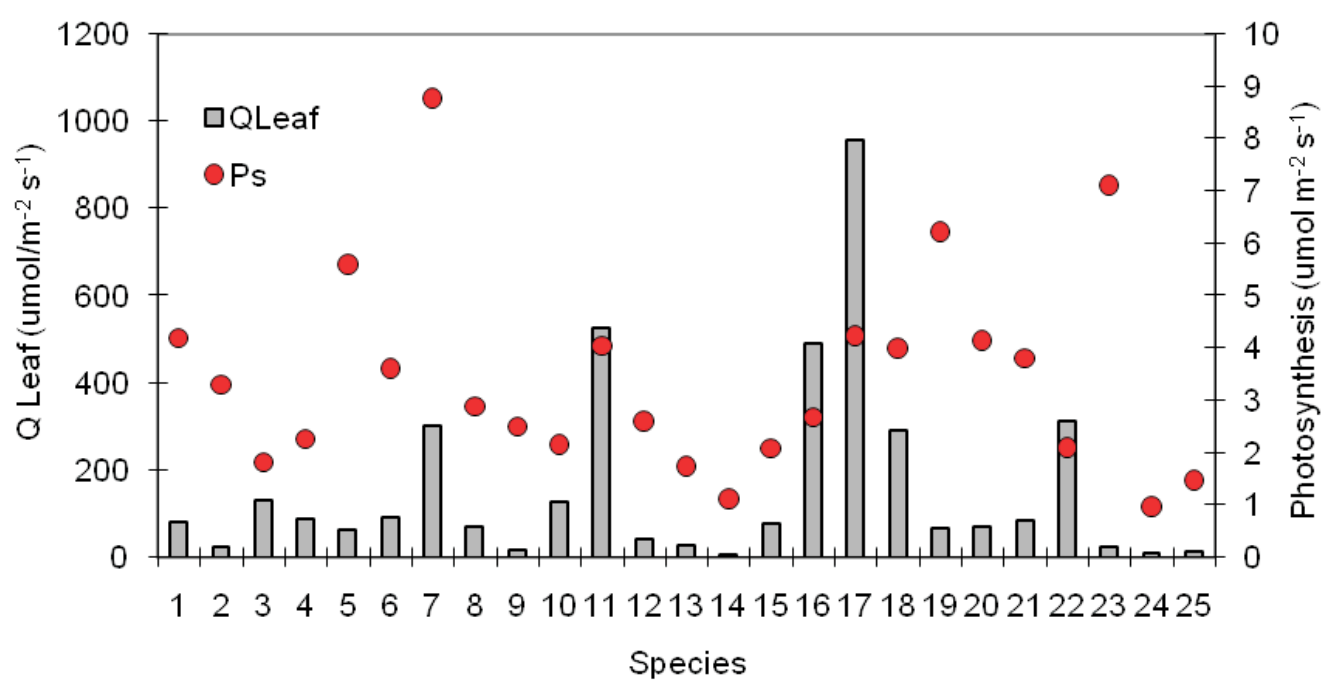

Figure 4. Correlation between photon flux (QLeaf) and photosynthesis (Ps) In Citalahab Plot (name of species is presented in Table 3 )

\section{B. Discussion}

The significant differences between the response of physiological characteristics and environmental conditions were represented by tree species. The response of physiological characteristic showed typical acclimation to sunlit condition such as increasing $\mathrm{CO}_{2}$ assimilation rate.

The results of this study agree with some findings that leaf photosynthesis in trees fairly variable with maximum values under natural conditions ranged from $3-30 \mu \mathrm{molm}^{-2} \mathrm{~s}$. The values varies between $2-25 \mu \mathrm{molm}^{-2} \mathrm{~s}^{-1}$ for deciduous broad leafed trees, $2-10 \mu$ molm $^{-2} \mathrm{~s}$ for coniferous trees, $3-6 \mu$ molm $^{-2} \mathrm{~s}$ for certain broad leafed species such as Quersus and Fagus, more than $25 \mu_{\text {molm }}^{-2} \mathrm{~s}$ for poplar, oil palms and eucalypt (Raghavendra, 1991). Photosynthesis of Shorea was reported of $7-21 \mu \mathrm{molm}^{-2} \mathrm{~s}$, Shorea balangeran $21.9 \mu_{\text {molm }}^{-2} \mathrm{~s}$ in Central Kalimantan, Acacia mangium of $24.2 \mu \mathrm{molm}^{-2} \mathrm{~s}, 16$ for Hopea odorata, $27.8 \mu_{\mathrm{molm}}^{-2} \mathrm{~s}$ for Ochroma lagopus (Chazdon et al., 1996; Press et al., 1996; Matsumoto et al., 2003). Photosynthesis of tropical woody plants for the first stage of succession ranged $10-20 \mu$ molm $^{-2} \mathrm{~s}$, scarcely 25 $\mu$ molm $^{-2} \mathrm{~s}^{-}$(Larcher, 1995).

The plasticity of stomatal conductance ( $\mathrm{gs}$ ) under relatively shade and lower temperature was low, between $0.030 \mathrm{molm}^{-2} \mathrm{~s}^{-1}$ to $0.263 \mathrm{molm}^{-2} \mathrm{~s}^{-1}$ in Cikaniki and between $0.043 \mathrm{molm}^{-2} \mathrm{~s}^{-1}$ to 0.223 molm $\mathrm{s}^{-1}$ in Citalahab. Findings were reported that gs of fast growing of $S$. balangeran and $A$. mangium were $0.49 \mathrm{molm}^{-2} \mathrm{~s}^{-1}$ (Takahashi et al., 2005; Takahashi et al., 2006) and $1.3 \mathrm{molm}^{-2} \mathrm{~s}^{-1}$ (Matsumoto et al., 2003). The high gs play a role for high capacity of ventilation due to high transpiration rate in open site, being able to avoid extremely increase of leaf temperature.

This study suggested that for evaluation of the appropriate tree species, morphological and photosynthetic characteristic of leaves are suitable indicators. In general, sun leaf has higher light saturated $\mathrm{CO}_{2}$ assimilation rate and lower apparent quantum yield of $\mathrm{CO}_{2}$ assimilation rate compared with shade leaf (Boardman, 1977; Larcher, 1995; Press et al., 1996). Shade leaf has high light-use efficiency for $\mathrm{CO}_{2}$ assimilation under low light condition due to high accumulation light harvesting system in photosynthesis, however, under open condition, shade leaf does not have high light-use efficiency and the reduction of $\mathrm{CO}_{2}$ assimilation rate often occurs due to light oxidation by excess light energy called photo-inhibition (Clearwater et al., 1999). Furthermore, Press et al. (1996) demonstrated that the degree of photosynthetic plasticity in response to changes of light regimes was high in the most-light demanding species, therefore it is recommendable to select trees which have higher $\mathrm{CO}_{2}$ assimilation rate of sunlit leaf and higher degree of plasticity. 
Abiotic factors such as light, temperature, $\mathrm{CO}_{2}$ concentration, vapour pressure deficit and nutrient status have a major effect on net photosynthesis, and thus on growth and productivity. All environmental conditions that tend to reduce photosynthetic rate (e.g. low light, low temperature, low nutrient availability) reduce the photosynthetic carbon gain (Ceulmens and Sauger, 1991).

Photosynthetic capacity varies not only with environment but also with age and position of the leaves in the canopy. Stomatal conductance (and net photosynthesis) in Quersus reached a maximum several weeks after maximum leaf size. Leaves of 10-year old oil palm remainded photosynthetically active for 21 months. This has important implications for the whole-tree photosynthetic $\mathrm{CO}_{2}$ uptake (Ceulmens and Sauger, 1991).

Some important remarks should be made about the correct interpretation of the values of photosynthetic rate. First, growth conditions as well as the experimental methods have important implication on $\mathrm{CO}_{2}$ exchange rate. Plant raised under natural conditions and/or measured in situ tend to have higher $\mathrm{CO}_{2}$ exchange rate than do plants grown under controlled environment such as greenhouse condition. Therefore specification on tree size, measurements conditions and methods used are mentioned in this paper.

In many cases net photosynthesis has been found to be poorly correlated with growth rate for some reasons, i.e difference in leaf area, pattern of carbon partitioning and variation in wood and root respiration rate. The harvestable product of a tree (the stem) depends not only on the photosynthetic carbon uptake by the foliage but also on respiration of the various organs and carbon investment into renewable organs (leaves, fine roots) and non harvestable organs (branches and large roots). Consequently, there is no obvious relationship between photosynthesis and biomass production. However, a fast growing tree needs a high photosynthesis, but the reverse is not necessarily true (Raghavendra, 1991).

\section{CONCLUSION}

1. The results showed that there was a wide range of variation of $\mathrm{CO}_{2}$ assimilation rate between tree species. The overall $\mathrm{CO}_{2}$ absorption rate ranged $1.1913-31.3875 \mu$ molm $^{-2} \mathrm{~s}^{-1}$, the highest rate was reached by Lithocarpus sp.1 (pasang parengpeng) (31.3875 $\left.\mu_{\text {molm }} \mathrm{s}^{-1}\right)$, followed by Litsea noronbae (huru lumlum) $\left(21.5750 \mu\right.$ molm $\left.^{-2} \mathrm{~s}^{-1}\right)$, Saurania nudiflora (kilebo) (11.8175 $\mu_{\text {molm }}^{-2} \mathrm{~s}^{-1}$ ), Vernonia arborea (hamirung) $\left(6.7125 \mu \mathrm{molm}^{-2} \mathrm{~s}^{-1}\right)$ and Litsea sp.1 (huru bodas) $\left(6.2725 \mu \mathrm{molm}^{-2} \mathrm{~s}^{-1}\right)$.

2. Different microclimate conditions during the measurements resulted in variance $\mathrm{CO}_{2}$ assimilation rate. The rate of $\mathrm{CO}_{2}$ assimilation was affected by photon flux (Q leaf). Incident radiation and $\mathrm{Q}$ leaf also affected stomatal conductance and thus rate of transpiration. Correlation between stomatal conductance and transpiration under certain environmental condition was considerably high.

3. Some remark need to be measurement of $\mathrm{CO}_{2}$ assimilation.

\section{ACKNOWLEDGEMENT}

We thank to Mount Halimun-Salak National Park for study site, cooperation and assistance during data collection. Research Competitive Programme The Indonesian Institute of Sciences for financial supports.

\section{REFERENCES}

Ashton, M.S. 1998. Seedling Ecology of MixedDipterocarp Forest. In: Appanah, S. and J.M. Thurnbull (Eds.), Review of Dipterocarps, Taxonomy, Ecology and Silviculture. CIFOR, Bogor, pp. 89-98.

Boardman, N.K. 1997. Comparative photosynthesis of sun and shade plants. Annu. Rev.Plant Physiol. 28: 57-107.

Brown, S. 1997. Estimating biomass and biomass change of tropical forest, a primer. FAO Forestry Paper 134. FAO, Rome.

Chazdon R.L., R.W. Pearey, D.W. Lee and N. Fetcher. 1996. Photoshyntetic responses of tropical forest plants to contransting light environments. In: Mulkey S.S., R.L. Chazdon and A.P. Smith (Eds.) Tropical 
Forest Plant Ecophysiology. Chapman and Hall, Newyork. pp. 5-55

Convention of Biological Diversity (CBD). 2008. Biodiversity: A Missing Link for Mitigating Climate Change. World Environment Day Celebrated in Montreal (Press Release).

Ceulmens R.J. and B. Sauger. 1991. Photosynthesis. In: Raghavendra. A.S. 1991. Physiology of Trees. Wiley \& Sons Publ. New York 262p.

Clearwater, M.J., R. Susilawati, R. Effendi and P.R.van Gardingen. 1999. Rapid photosynthetic acclimation of Shorea johorensis seedlings after logging disturbance in Central Kalimantan. Oceanologia 121:478-488.

Cox, G.W. 1967. Laboratory Manual of General Ecology. M.C. Crown, Iowa.

Greigh-Smith, P. 1964. Quantitative Plant Ecology. Second Edition. Butterworth, London.

Lacher, W. 1995. Physiological Plant Ecology ( $\left.3^{\text {rd }}\right)$. Springer, Berlin.

Long, S.P. and J.E. Hallgren. Measurement of $\mathrm{CO}_{2}$ assimilation by plants in the field and the laboratory. In: Hall, D.O., M.O. Scurlock, H.R. Bolhar-Nordenkampf, R.C. Leegood and S.P. Long (Eds.). Photosynthesis and Production in a Changing Environment : A Field and Laboratory Manual. Chapman \& Hall. 464 p.

Matsumoto, Y., Y. Maruyama, A. Uemura, H. Shigenaga, S. Okuda, H. Harayama, H. Kawarasaki, L.H. Ang and S.K. Yap. 2003. Gas exchange and turgon maintenance of tropical tree species in Pasoh forest reserve. In: Okuda, T., Manokaran, N., Matsumoto, Y., Niiyama, K., Thomas, S.C., Ashton, PS. (Eds.). Ecological of Lowland Rain Forest in Southeast Asia. Springer-Verlag, Tokyo, pp. 241-250.

Morenco, R.A. and G. Viera. 2005. Specific leaf area and photosynthetic parameters of tree species in the forest undestory as a function of microsite light environment in Central Amazonia. J. Tropical Forest Science 17 : 265278.

Press, M.C., N.D. Brown, M.G. Baker and S.W. Zipperlen. 1996. Photosynthetic responses to light in tropical rain forest tree seedlings. In: Swaine, M.D., (Ed.). The Ecology of Tropical Forest Tree Seedlings. UNESCO, Paris, pp. 41-58.

Takahashi, K., M. Osaki, M. Shibuya, Y. Tamai, H. Saito, L.H. Swido, S.J. Tuah, A.R. Susanto, C. Pidjath and P. Erosa. 2005. Growth phenology and photosinthetic traits of tree species native to peat-swamp forest. Annual Report: Environmental Conservation and Land Use Management of Wetland Ecosystem in Southeast Asia. p. 68-70.

Takahashi, K., M. Shibuya, Y. Tamai, H. Saito, L.H. Swido, S.J. Tuah, A.R. Susanto and P. Erosa. 2006. Morphological and photosynthetic characteristics of Shorea selanica and $S$. balangeran sapling planted at open and understory conditions on peat soil in Central Kalimantan. Annual Report: Environmental Conservation and Land Use Management of Wetland Ecosystem in Southeast Asia. p.62-68. 
Physiological Characteristics Related to Carbon Sequestration of Tree Species tn Highland Forest Ecosystem ..... (Nuril Hidayati)

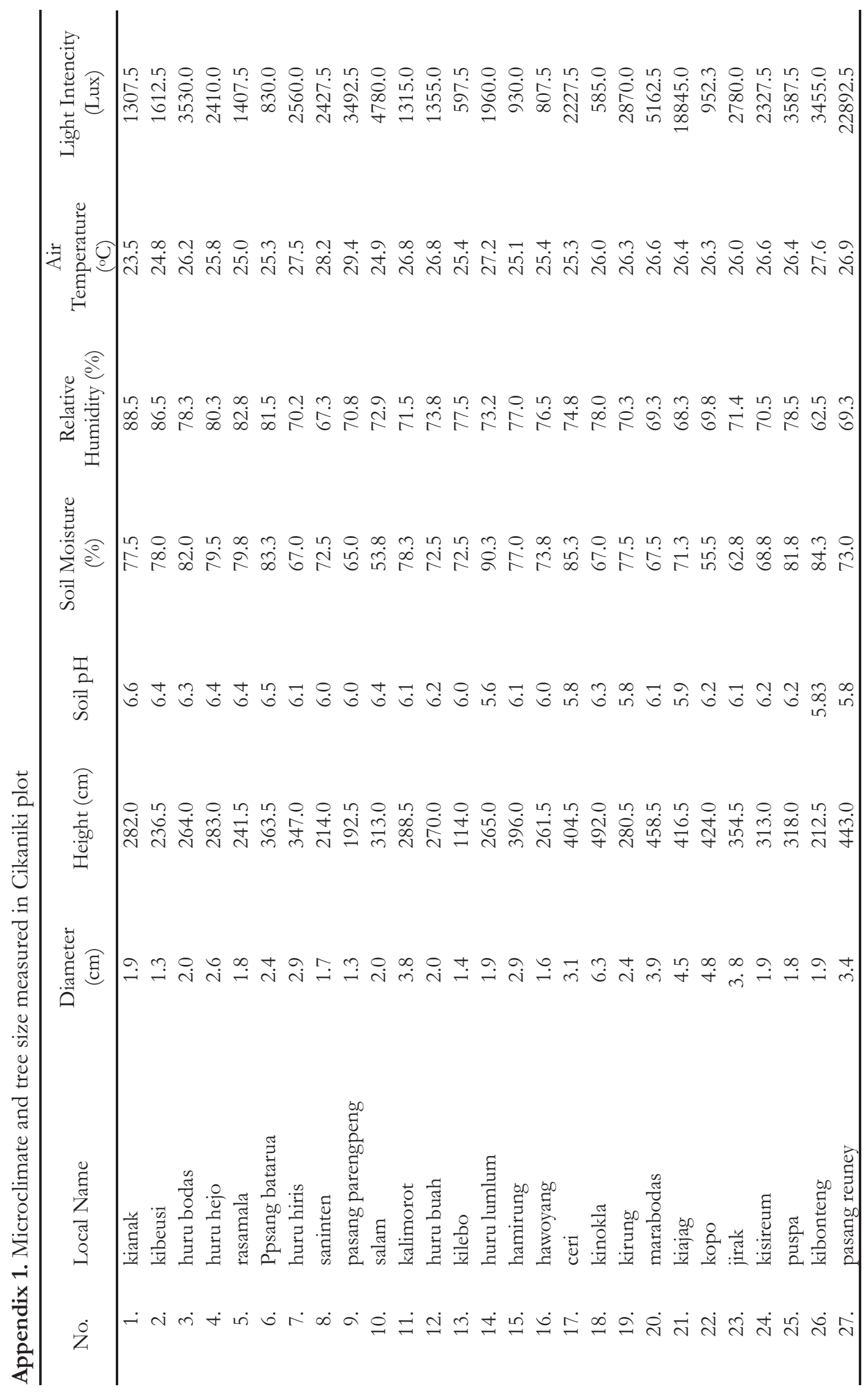




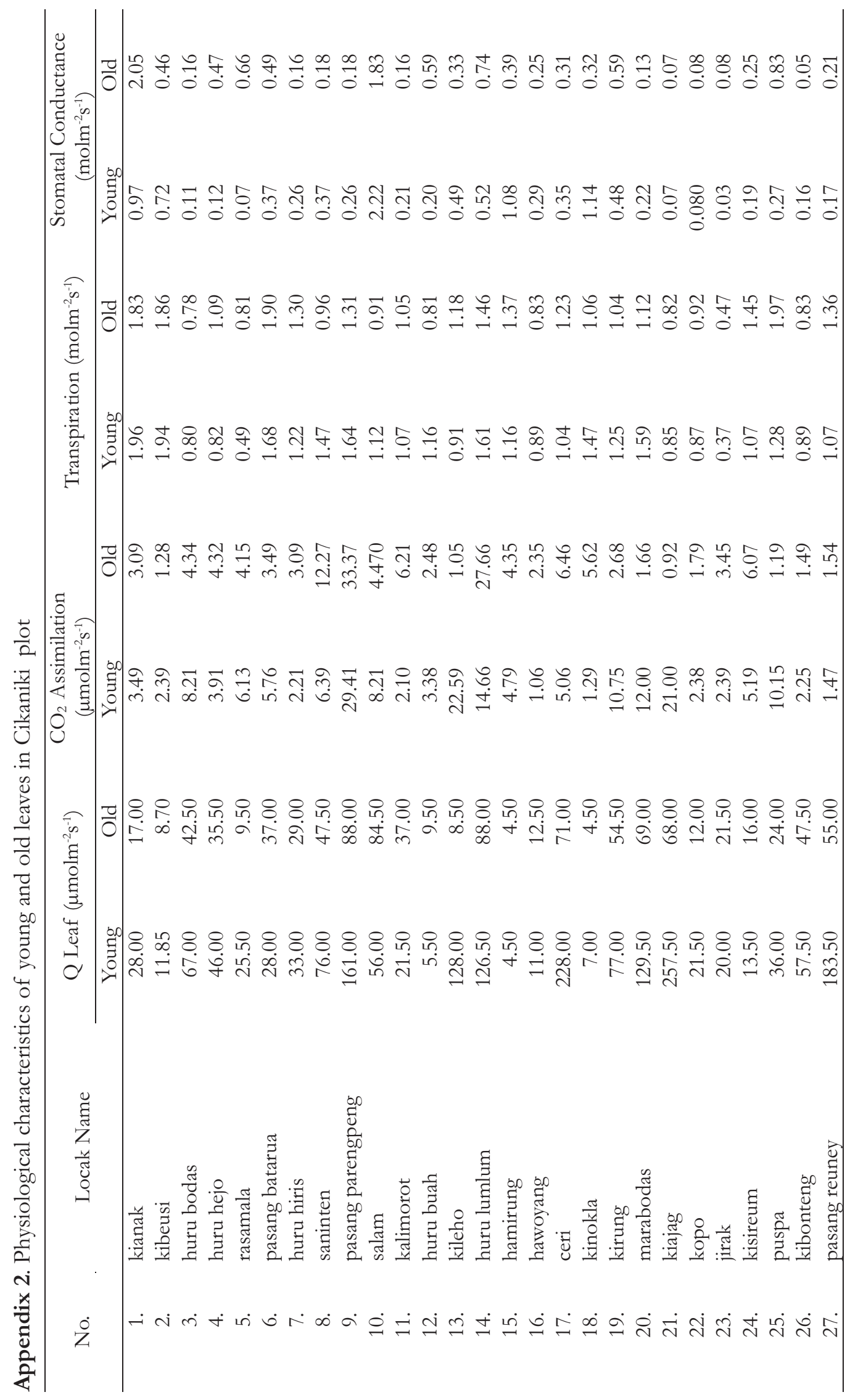


Physiological Characteristics Related to Carbon Sequestration of Tree Species tn Highland Forest Ecosystem ..... (Nuril Hidayati)

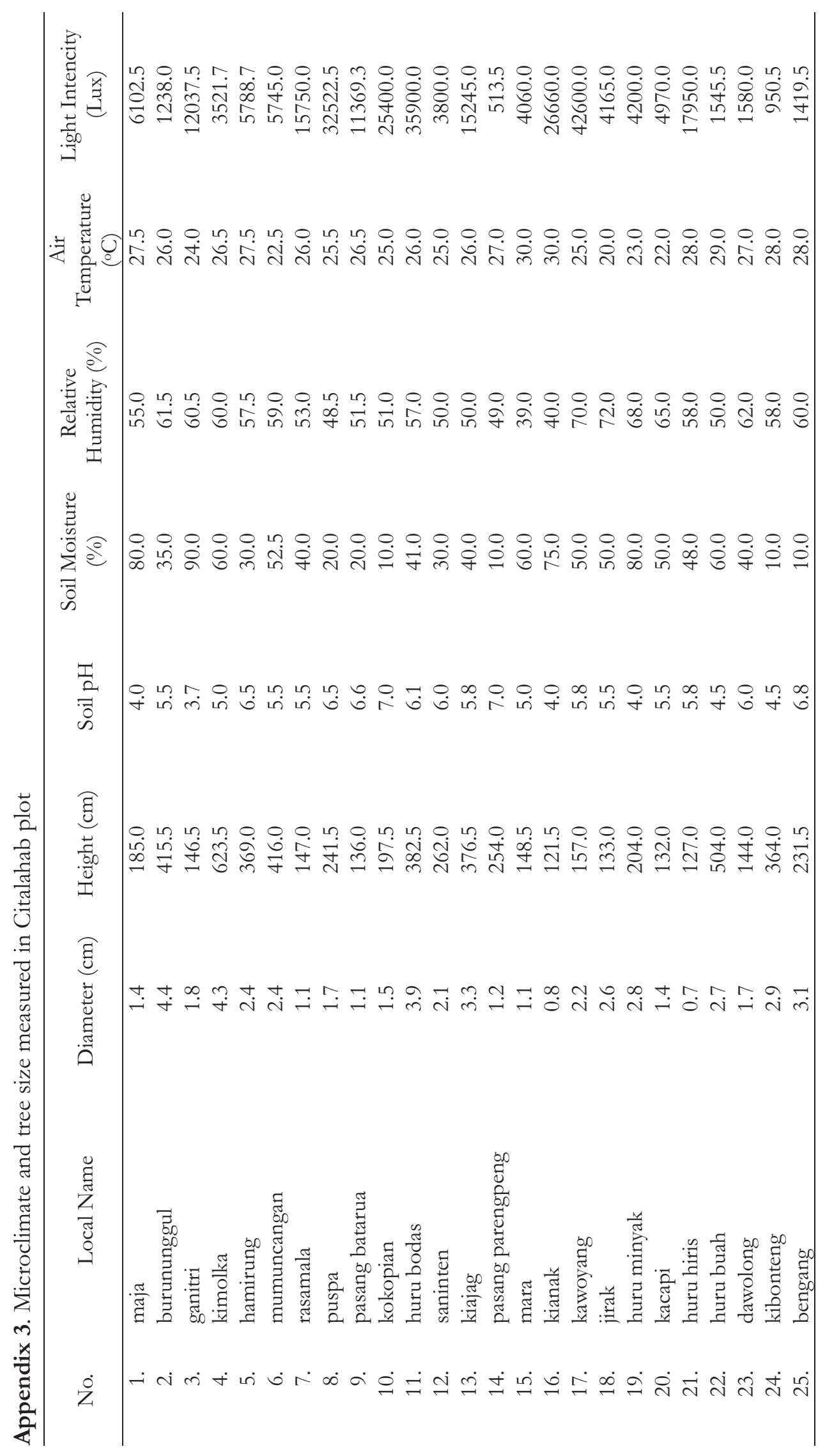

